\title{
Technologies for teaching DHI students using Libras: a systematic review
}

\author{
Antônio Carlos de F. Silva ${ }^{1}$, Weider A. Barbosa ${ }^{1}$, \\ Cássio L. Rodrigues ${ }^{1}$, Deller J. Ferreira ${ }^{1}$ \\ ${ }^{1}$ Instituto de Informática, Universidade Federal de Goiás (UFG), Goiânia-GO, Brasil \\ \{antoniofreitas, weiderbarbosa, cassio, deller\}@inf.ufg.br
}

\begin{abstract}
The Sign Language (SL) is not limited to communication, it is also important for learning, access to information, cultural and social interactions. This paper presents a Systematic Literature Review (SR) in order to identify the technologies that support the teaching of Deaf and Hearing Impaired (DHI) students by means of Brazilian Sign Language (Libras). We have found technologies that are applied on different courses and contexts, highlighting the importance of SL in education. Considering the technologies analyzed in this SR, educational games stand out, while applications for Web content access from mobile devices are not regarded. During this SR, we analyzed 105 papers and the results show that there is a need to develop applications to support the education of DHI.
\end{abstract}

\section{Introduction}

The Sign Language (SL) is the natural language and is commonly used for the majority the Deaf or Hearing Impaired (DHI) people. In Brazil, Brazilian Sign Language (Libras) is the official SL [Monteiro et al. 2013]. Brazil is considered a monolingual country, despite having more than 170 different indigenous languages and the SL. This encourages schools teach only one language with quality, the Portuguese as main language, making the Libras a second language [Quadros 2005].

The Brazilian Legislation establishes that is mandatory for educational institutions to provide resources to support the DHI students, but the solutions are usually limited to just hiring professional interpreters of Libras [Quadros 2005, Saito and Ribas Ulbricht 2012]. One possible reason for educational institutions to be limited to hiring interpreters can be characterized by lack of specific technologies that support the teaching to DHI students [Dos Passos Canteri et al. 2015].

There are many other challenges related to DHI education, such as, to keep the students motivated, particularly when they have different levels of expertise and different communication barriers to overcome. Another challenge is the lack of signs to express technical terms used in some specific areas of knowledge, for example, in teaching of mathematics and computer programming [Oliveira et al. 2015, Medeiros et al. 2014].

Vygotsky [Vygotsky et al. 2012] and Sacks [Sacks 1989] present the importance of language in education and social interactions, once thoughts and feelings are expressed through language. Thus DHI students face more difficulties to build knowledge comparing to listeners students. The SL goes beyond making communication 
V Congresso Brasileiro de Informática na Educação (CBIE 2016)

Anais do XXVII Simpósio Brasileiro de Informática na Educação (SBIE 2016)

possible, enabling DHI people to access new experiences, such as, education and culture [Sacks 1989, Guimarães et al. 2014]. However, the use of SL is a necessary but not sufficient condition for DHI students learning.

DHI students do not have the ability to concurrently register the constructed concepts in the classroom such as listeners students who can use simultaneously other channels, as vision and hearing. So, the listeners students can perform concurrent tasks during class, like to take notes. It is difficult for DHI students to assimilate class content, since the resources that support the acquisition of concepts transmitted in the classroom are limited. Thus, educational resources to assist DHI students are needed [Saito et al. 2011, Bueno and García 2015].

The use of texts and captions are not enough to mitigate the challenges faced by DHI students to use a software, because they have reading difficulties. According to Kargin [Kargin et al. 2014] DHI students finish high school with reading levels compared to listeners students from $4^{\text {th }}$ and $5^{\text {th }}$ Grade. However deafness does not affect intellectual ability, this difficulty is often by previous experiences, where the DHI person was submitted the evasive methods to acquire oral language [Sacks 1989, Gesser 2009, Moura et al. 2013]. So, other approaches are needed in the education of DHI students.

In this paper, we aim to conduct a Systematic Literature Review (SR) on the use of technology to support teaching DHI students using Libras. A SR can be seen as a broader literature review of the primary studies, having as objective to identify the amount, research and results available on a particular subject. The results of the SR can be used by other researchers in future studies [Barbosa and Júnior 2013].

The paper is divided in five sections. Section 2 presents a background about Libras. Section 3 describes the planning and conduct of SR. Section 4 shows the answers to the research questions. And, finally, Section 5 presents a brief discussion as a conclusion.

\section{Brazilian Sign Language}

According to the Brazilian Institute of Geography and Statistics (IBGE) [IBGE 2010] in Brazil about 9.7 millions (5.1\%) the of population have DHI, and one million of them are children or teenagers up to 19 years of age. Of this total, 344.2 thousand are deaf and 1.7 million have hard of hearing. And 60\% of DHI population in Brazil know Libras.

According to the 22th DECEMBER, 2005, Brazilian Legislation DECREE N ${ }^{\circ}$ 5.626 [Brasil 2005] hearing impaired is a bilateral, partial or total, of 41 decibels (dB) or more, measured by an audiogram in the frequencies of $500 \mathrm{~Hz}, 1.000 \mathrm{~Hz}, 2.000 \mathrm{~Hz}$ and $3.000 \mathrm{~Hz}$. And a Deaf person is characterized by the hearing loss and who understands and interacts with the world through visual channels, manifesting mainly by SL.

The DHI people were deprived of their natural language for several centuries. The SL has been seen as a secret code of the DHI people and eventually being banned in some places [Gesser 2009]. In 2002 the Brazilian Sign Language stopped being used informally, when was recognized as legal means of communication and expression by the 24th APRIL, 2002 FEDERAL LAW No 10.436 [Brasil 2002].

The Libras has its origins in two others SL: French Sign Language (LSF) and Ka'apor Sign Language. Ka'apor are a group of indigenous Brazilians from a protected reserve in the state of Maranhão, where there is a high number of DHI. The SL is not 
V Congresso Brasileiro de Informática na Educação (CBIE 2016)

Anais do XXVII Simpósio Brasileiro de Informática na Educação (SBIE 2016)

a universal language, each country adopts its own grammar. In Brazil there are dialect variations in different regions of the country, this shows the plainness of SL [Gesser 2009, Lima et al. 2013].

The Libras is a language of visual-spatial mode, composed by five parameters: combining hand shapes, movements, points of articulation, orientation and facial and/or body expressions. So, the oral language and SL are similar in structure [Gesser 2009]. The words in Libras are not constructed from sounds that combine, but hands that move in space and which are organized simultaneously and nonlinear [Peixoto 2006].

\section{Systematic Literature Review}

A SR concerning technologies to support teaching to DHI students using Libras was held following the guidelines for performing SR defined by Kitchenham [Kitchenham and Charters 2007]. The SR was divide into three phases: Planning, Conduction and Dissemination.

The planning was done after identifying the need for a systematic review and preparation of the research protocol. The protocol was identified research questions and search strategy, along with the inclusion and exclusion criteria for selection of papers.

The conduction phase was divided into two stages: selection of papers and data extraction. The selection consists of the protocol along with the search strategy in order to identify available papers. Identified the works, begins the selection of items by applying the inclusion and exclusion criteria. Data extraction was performed on the papers included in the selection phase, where the work was read in full and the data were extracted in order to answer the research questions.

Finally, the dissemination phase was the build of extracted data to answering the research questions, and writing this paper. In the next subsections we present the phases of planning and conduction of the SR.

\subsection{Planning}

The SR was carried out in order to answer the research questions identified in Table 1. The first column of the table shows the ID of research question that will be used in the rest of this paper, while the second column, shows the research questions.

Tabela 1. Research questions to SR.

\begin{tabular}{ll}
\hline$\#$ & Research question \\
\hline Q1 & $\begin{array}{l}\text { What are the technologies used to support teaching the } \\
\text { DHI using Libras? }\end{array}$ \\
\hline $\mathbf{Q 2}$ & $\begin{array}{l}\text { What are the disciplines that were covered by the } \\
\text { technologies identified by the Q1? }\end{array}$ \\
\hline Q3 & $\begin{array}{l}\text { Which approaches (eg, digital educational tools, games, etc.) } \\
\text { have been used for teaching the disciplines identified in Q2? }\end{array}$ \\
\hline \multirow{2}{*}{ Q4 } & $\begin{array}{l}\text { What platforms (Web, Desktop or Mobile) were used by } \\
\text { the technologies identified by the Q1? }\end{array}$ \\
\hline \multirow{2}{*}{ Q5 } & $\begin{array}{l}\text { What methods of assessment were used to evaluate the } \\
\text { technologies identified by the Q1? }\end{array}$ \\
\hline
\end{tabular}


V Congresso Brasileiro de Informática na Educação (CBIE 2016)

Anais do XXVII Simpósio Brasileiro de Informática na Educação (SBIE 2016)

The keywords were identified and classified in fields (education, deafness, technology and sign language). From the keywords identified and classified, we created two search strings, English and Portuguese, according to Table 2. The logical operators and/or were used to create the search strings and * to represent the possible variations of each search term. For example, the term learn* will return variables such as learn, learning, learned and learner.

Tabela 2. Search strings in English and Portuguese.

\begin{tabular}{|c|c|}
\hline English & $\begin{array}{l}\text { ((education or learn* or teach*) } \\
\text { and } \\
\text { (technology or software or application or system or program or tool)) } \\
\text { and } \\
((\text { deaf* or "hearing impaired"or "hard of hearing") } \\
\text { and } \\
\text { ("sign language"and Libras }))\end{array}$ \\
\hline Portuguese & $\begin{array}{l}\text { ((educa* or ensino or aprendizado) } \\
\text { and } \\
\text { (tecnologia or software or aplicação or sistema or programa or ferramenta })) \\
\text { and } \\
\text { ((surdo* or "deficiente auditivo") } \\
\text { and } \\
\text { ("língua de sinais"and Libras }))\end{array}$ \\
\hline
\end{tabular}

The digital libraries (IEEE Xplorer (ieeexplore.ieee.org), ACM Digital Library (dl.acm.org), Scopus (www.scopus.com) and Science Direct (www.sciencedirect.com)) were selected by contemplating the criteria: (i) Digital libraries consolidated in the Computer Science; (ii) Digital libraries that enable search by string with keywords; and (iii) Digital libraries that enable online access.

The criteria for inclusion and exclusion were defined after identifying the digital libraries, in order to answer the research questions and are presented in Table 3.

Tabela 3. Inclusion and exclusion criteria of the papers.

\begin{tabular}{ll}
\hline \multirow{2}{*}{ Inclusion } & I1 Papers written in English \\
& I3 Papers written in Portuguese \\
& E1 Papers that are not meant for the education of DHI people \\
E2 Papers that do not show results \\
Exclusion & E3 Papers published before 2010 \\
& E4 Papers that do not answer the research questions \\
& E5 Papers that do not use Libras \\
\hline
\end{tabular}

\subsection{Conduction}

The two versions of search string were applied to the selected digital libraries and exclusion criterion $\mathbf{E 3}$ was applied directly to the digital libraries, since it is possible to filter papers per year in all bases considered. The digital Libraries IEEE Xplorer and Science Direct did not return papers in Portuguese. 
V Congresso Brasileiro de Informática na Educação (CBIE 2016)

Anais do XXVII Simpósio Brasileiro de Informática na Educação (SBIE 2016)

The search returned 105 papers, distributed according to Table 4. Among the 105 papers, there were 11 duplicates and 12 were considered relevant to research in the selection stage, according to the inclusion and exclusion criteria after reading the title and abstract.

Tabela 4. Papers found in SR.

\begin{tabular}{lc|ccc|cc}
\hline & & \multicolumn{3}{|c|}{ Selection } & \multicolumn{2}{c}{ Extraction } \\
\hline Digital Library & Quantity & Duplicates & Included & Excluded & Included & Excluded \\
\hline IEEE Xplorer & 34 & 0 & 3 & 31 & 1 & 2 \\
ACM Digital Library & 15 & 2 & 2 & 11 & 2 & 0 \\
Scopus & 50 & 7 & 7 & 36 & 3 & 4 \\
Science Direct & 6 & 2 & 0 & 4 & 0 & 0 \\
\hline Total & 105 & 11 & 12 & 82 & 6 & 6 \\
\hline
\end{tabular}

Six papers were excluded at this stage. Four of them were excluded for not having results focused on education of DHI people and two for not answering the research questions.

\section{Results}

In this section, the research questions are answered by means of a descriptive analysis of the selected papers in this SR. The Table 5 presents the references and titles of six papers analyzed in order to answer research questions listed in Table 1.

Tabela 5. References of papers analyzed to SR.

\begin{tabular}{ll}
\hline Reference & Title \\
\hline [Oliveira et al. 2015] & $\begin{array}{l}\text { A comparative study of the acceptability of signs for the } \\
\text { Brazilian sign language created in person and remotely }\end{array}$ \\
\hline [Boscarioli et al. 2012] & $\begin{array}{l}\text { Avaliação e design de interação de jogos voltados ao } \\
\text { aprendizado de crianças surdas }\end{array}$ \\
\hline [Moura et al. 2013] & $\begin{array}{l}\text { Luz, Câmera, Libras!: How a mobile game can improve } \\
\text { the learning of sign languages }\end{array}$ \\
\hline [Guimarães et al. 2014] & $\begin{array}{l}\text { Sign language writing acquisition - Technology for a } \\
\text { writing system }\end{array}$ \\
\hline [Monteiro et al. 2013] & $\begin{array}{l}\text { Using mediated communication to teach vocational } \\
\text { concepts to deaf users }\end{array}$ \\
\hline [Dos Passos Canteri et al. 2015] & $\begin{array}{l}\text { Video games in education of Deaf children: A set of } \\
\text { pratical design guidelines }\end{array}$ \\
\hline
\end{tabular}

Table 5 presents the references used to identify which papers were analyzed to answer the research questions in the next subsections.

\subsection{Answers to Q1}

During the SR we identified seven technologies. Many papers were rejected for not having results, according to exclusion criterion E1. The technologies evaluated in the papers included in this SR are shown in Table 6. The first column of the table presents the list of reference papers, the second presents the technologies and the last column presents the number of different types of technology identified. 
V Congresso Brasileiro de Informática na Educação (CBIE 2016)

Anais do XXVII Simpósio Brasileiro de Informática na Educação (SBIE 2016)

Tabela 6. Technologies evaluated by the papers identified in this SR.

\begin{tabular}{llc}
\hline Reference & Technology & Quantity \\
\hline [Oliveira et al. 2015] & Web Forum Tool & 1 \\
\hline [Boscarioli et al. 2012] & $\begin{array}{l}\text { Multi-Trilhas } \\
\text { Libras - Brincando e Aprendendo }\end{array}$ & 2 \\
\hline [Moura et al. 2013] & Luz, Câmera, Libras! & 1 \\
\hline [Guimarães et al. 2014] & SignWriting & 1 \\
\hline [Monteiro et al. 2013] & Web Navigation Helper & 1 \\
\hline [Dos Passos Canteri et al. 2015] & Jigsaw Puzzle Game & 1 \\
\hline Total & & 7 \\
\hline
\end{tabular}

- Web Forum Tool is a Web forum for creating new signs for untranslated terms directly to Libras. In the Web Forum Tool, a new thread is created for each word you want to translate. Users discuss and submit their suggestions concerning the term translated. The suggestions are sent in video format and evaluated by other users. After evaluated, the suggested translation that received most votes is selected [Oliveira et al. 2015].

- Multi-Trilhas is an educational game to help DHI students in the acquisition of written Portuguese as a second language. The game employs verbs, nouns, adjectives and pronouns in two languages: Libras and Portuguese. This tool facilitates the understanding of the material by means of multimedia support [Boscarioli et al. 2012].

- Libras - Brincando e Aprendendo is a set of educational games for teaching of Libras that focuses on interdisciplinary concepts, for example, mathematics and science. The educational games use images in order to teach the DHI students the meaning and theme concepts [Boscarioli et al. 2012].

- Luz, Câmera, Libras! is an educational game for creating a learning session between two players, where the basic signs of Libras can be learned during entertainment. Both players must be friends on Facebook and one player records a video of a word using Libras and sends it to your opponent along with three options of words. The two player must guess what in the word among three options and sent a reply back [Moura et al. 2013].

- SignWriting is a writing system for expressing the signs and hand movements. The system can be used by DHI and hearing to communicate through written language. SignWriting facilitates communication and access to information, culture and social interactions [Guimarães et al. 2014].

- Web Navigation Helper (WNH) is a script used as an extension to the web browser. The WNH allows users to create dialogues mediators in Libras to help other DHI users to overcome accessibility barriers in a system designed to listeners [Monteiro et al. 2013].

- Jigsaw Puzzle Game is a educational game of jigsaw puzzle to supports the teaching of various subjects, for example, animals, food, hygiene and transport. The game allows the teacher to choose a topic that will be addressed by the DHI students facilitating the learning of various subjects [Dos Passos Canteri et al. 2015]. 
V Congresso Brasileiro de Informática na Educação (CBIE 2016)

Anais do XXVII Simpósio Brasileiro de Informática na Educação (SBIE 2016)

\subsection{Answers to $\mathrm{Q} 2$}

The second research question is about the disciplines covered by the technologies identified in the papers analyzed in SR. The Table 7 presents the reference of papers and disciplines.

Tabela 7. Disciplines covered by the technologies identified in SR.

\begin{tabular}{ll}
\hline Reference & Discipline \\
\hline [Oliveira et al. 2015] & Java Programming \\
\hline [Boscarioli et al. 2012] & Portuguese, Libras and high school disciplines \\
\hline [Moura et al. 2013] & Libras \\
\hline [Guimarães et al. 2014] & Portuguese and Libras \\
\hline [Monteiro et al. 2013] & Libras \\
\hline [Dos Passos Canteri et al. 2015] & Libras and high school disciplines \\
\hline
\end{tabular}

All seven technologies analyzed are interdisciplinary, highlighting that the Web Forum Tool can be used in various disciplines which require signs for terms that are not translated directly to Libras. For example, the term debug, that is used in computer programming courses and there is no direct translation for Libras. The technology also maintains a historical data base for the translated terms and makes it usable as a glossary for other disciplines that require the use of previously translated terms. The Web Forum Tool is a collaborative and distributed technology, minimizing the risk of creating a regionally restricted glossary.

Three technologies (Libras - Brincando e Aprendendo, Jigsaw Puzzle Game and Luz, Câmera, Libras!) are aimed to teach Libras as a first language. Two (Multi-Trilhas and SignWriting) are aimed to teaching Portuguese as a second language. And four are bilingual (Libras/Portuguese) (Web Forum Tool, Multi-Trilhas, SignWriting and WNH).

\subsection{Answers to Q3}

The third research question is about the teaching approach used in technologies identified in Q1. Table 8 presents the references of the papers identified in the SR and the approaches used.

Tabela 8. Approach used in technologies identified in SR.

\begin{tabular}{ll}
\hline Reference & Approach \\
\hline [Oliveira et al. 2015] & Web Forum \\
\hline [Boscarioli et al. 2012] & Educational Game \\
\hline [Moura et al. 2013] & Educational Game \\
\hline [Guimarães et al. 2014] & SignWriting \\
\hline [Monteiro et al. 2013] & Dialogues Mediator \\
\hline [Dos Passos Canteri et al. 2015] & Educational Game \\
\hline
\end{tabular}

The main approach was educational games (four technologies), as shows in Table 8. Two technologies are Web, WNH and Web Forum Tool. And one is a sign writing system, SignWriting. 
V Congresso Brasileiro de Informática na Educação (CBIE 2016)

Anais do XXVII Simpósio Brasileiro de Informática na Educação (SBIE 2016)

\subsection{Answers to Q4}

The fourth research question addresses the platforms used in the technologies identified by Q1. Table 9 presents the platforms of each papers analyzed by SR. We identified two technologies for mobile devices (Luz, Câmera e Libras! and SignWriting), two Web applications (Web Forum Tool and WNH), one Desktop applications and one that the platform used was not informed.

Tabela 9. Platforms used by the technologies identified by Q1.

\begin{tabular}{ll}
\hline Reference & Platform \\
\hline [Oliveira et al. 2015] & Web \\
\hline [Boscarioli et al. 2012] & Desktop \\
\hline [Moura et al. 2013] & Mobile \\
\hline [Guimarães et al. 2014] & Mobile \\
\hline [Monteiro et al. 2013] & Web \\
\hline [Dos Passos Canteri et al. 2015] & Uninformed \\
\hline
\end{tabular}

In Brazil, the media are the most diverse possible, and the television (TV) is the main media. According to the Secretary of Social Communication of Presidency of the Republic (SECOM) [SECOM 2015] in 2015, 48\% of Brazilians had Internet access, being that $66 \%$ was conducted through mobile devices. Current papers do not exploit the possibilities of access to information. We have identified only two technologies for mobile devices and nothing for Digital TV.

\subsection{Answers to Q5}

The last research question is about the evaluation methods used in the papers identified by SR. Table 10 presents the references of the analyzed papers and evaluation methods.

Tabela 10. Evaluation method used by the papers identified by SR.

\begin{tabular}{ll}
\hline Reference & Evaluation \\
\hline [Oliveira et al. 2015] & Questionnaire \\
\hline [Boscarioli et al. 2012] & Cognitive Walkthrough and Semiotic Protocol \\
\hline [Moura et al. 2013] & Server Data Analysis \\
\hline [Guimarães et al. 2014] & Questionnaire \\
\hline [Monteiro et al. 2013] & Questionnaire \\
\hline [Dos Passos Canteri et al. 2015] & Exploratory testing \\
\hline
\end{tabular}

Three papers identified by the SR used questionnaires to evaluate the analyzed technologies. Boscarioli [Boscarioli et al. 2012] addresses the human-computer interaction, and applies the Cognitive Walkthrough and Semiotic Protocol techniques for data evaluation. Oliveira [Oliveira et al. 2015] compare signs created in the classroom, remotely using questionnaire. The process of creating new terms is collaborative, and must involve Deaf students, teachers and interpreters of Libras. Data Analysis Server is used to evaluate the technology developed in Moura [Moura et al. 2013]. And Dos Passos [Dos Passos Canteri et al. 2015] perform exploratory testing for data analysis. 
V Congresso Brasileiro de Informática na Educação (CBIE 2016)

Anais do XXVII Simpósio Brasileiro de Informática na Educação (SBIE 2016)

\section{Conclusion}

In this work, a SR was held in order to answer the research questions presented in Table 1. After answering the research questions it is noted that all technologies included in SR proved to be interdisciplinary. This highlights the integration of Libras and other disciplines, and the need for educational resources that support teaching the DHI students using Libras in a wide spectrum of disciplines.

On the majority (57\%) of the evaluated technologies, educational games have been approached. The educational games were used through the visual elements, text and images for teach the specific subject. This fact highlights the potential use of educational games to teach DHI students. The answer to Q4 shows the need to direct efforts to the development of technologies to support teaching the DHI students to most used platforms, such as Digital TV and mobile devices.

The results show that, on one hand, the majority of works used informal evaluations, as questionnaires. On the other hand, many papers were rejected in this SR for not presenting any result based on any kind of evaluation of their technology for teaching DHI students. So, we can conclude that the results show a demand for the development of formal evaluation methods, geared to the software engineering domain, to be deployed when developing and evaluating educational technologies concerning people who needs Sign Language.

\section{Referências}

Barbosa, W. A. and Júnior, P. A. P. (2013). Um mapeamento sistemático sobre ferramentas de apoio ao ensino de algoritmo e estruturas de dados. In Anais do XXIV Simpósio Brasileiro de Informática na Educação (SBIE 2013).

Boscarioli, C., de Salles, C. G., Baqueta, J. J., and Colling, J. P. (2012). Avaliação de design de interação de jogos voltados ao aprendizado de crianças surdas. In Companion Proceedings of the 11th Brazilian Symposium on Human Factors in Computing Systems, IHC '12, pages 25-26, Porto Alegre, Brazil, Brazil. Brazilian Computer Society.

Brasil (2002). Lei $\mathrm{n}^{\circ}$ 10.436, de 24 de abril de 2002. Acessado em: 20/01/2016.

Brasil (2005). Decreto $\mathrm{n}^{0}$ 5.626, de 22 de dezembro de 2005. Acessado em: 08/12/2015.

Bueno, J. and García, L. S. (2015). Pesquisa-ação na construção de insumos conceituais de um ambiente computacional de apoio ao letramento bilíngue de crianças surdas. In Anais do XXVI Simpósio Brasileiro de Informática na Educação (SBIE 2015).

Dos Passos Canteri, R., García, L., De Souza, T., and Iatskiu, C. (2015). Video games in education of deaf children: A set of pratical design guidelines. ICEIS $2015-17$ th International Conference on Enterprise Information Systems, Proceedings, 3:122-129.

Gesser, A. (2009). Libras? que língua é essa?: crenças e preconceitos em torno da língua de sinais e da realidade surda. Parábola Ed.

Guimarães, C., Guardezi, J., and Fernandes, S. (2014). Sign language writing acquisition - technology for a writing system. Proceedings of the Annual Hawaii International Conference on System Sciences, pages 120-129.

IBGE (2010). Censo Populacional 2010. Instituto Brasileiro de Geografia e Estatística (IBGE)(29 de novembro de 2010). 
V Congresso Brasileiro de Informática na Educação (CBIE 2016)

Anais do XXVII Simpósio Brasileiro de Informática na Educação (SBIE 2016)

Kargin, T., Guldenoglu, B., and Miller, P. (2014). Examining the relationship between letter processing and word processing skills in deaf and hearing readers. Educational Sciences: Theory \& Practice, 14(6):2230-2238.

Kitchenham, B. and Charters, S. (2007). Guidelines for performing systematic literature reviews in software engineering. Technical report, Technical report, EBSE Technical Report EBSE-2007-01.

Lima, T., Rocha, M. S., Santos, T. A., Benetti, A., Soares, E., and de Oliveira, H. S. (2013). Innovation in learning-the use of avatar for sign language. In HumanComputer Interaction. Applications and Services, pages 428-433. Springer.

Medeiros, L., Brod Júnior, M., and Gomes, L. (2014). Logograms: Memory aids for learning, and an example with hearing-impaired students. Lecture Notes in Computer Science (including subseries Lecture Notes in Artificial Intelligence and Lecture Notes in Bioinformatics), 8519 LNCS(PART 3):207-216.

Monteiro, I., Da Silva Alves, A., and De Souza, C. (2013). Using mediated communication to teach vocational concepts to deaf users. Lecture Notes in Computer Science (including subseries Lecture Notes in Artificial Intelligence and Lecture Notes in Bioinformatics), 8011 LNCS(PART 3):213-222.

Moura, G., Vasconcelos, L., Cavalcanti, A., Breyer, F., Da Silva, D., Teixeira, J., Leão, C., and Kelner, J. (2013). Luz, câmera, libras!: How a mobile game can improve the learning of sign languages. Lecture Notes in Computer Science (including subseries Lecture Notes in Artificial Intelligence and Lecture Notes in Bioinformatics), 8013 LNCS(PART 2):266-275.

Oliveira, F., Gomes, G., De Freitas, A., De Oliveira, A., Silva, L., and Queiroz, B. (2015). A comparative study of the acceptability of signs for the brazilian sign language created in person and remotely. SIGCSE 2015 - Proceedings of the 46th ACM Technical Symposium on Computer Science Education, pages 207-211.

Peixoto, R. C. (2006). Algumas considerações sobre a interface entre a língua brasileira de sinais (libras) e a língua portuguesa na construção inicial da escrita pela criança surda. Cad Cedes, 26(69):205-29.

Quadros, R. d. (2005). O 'bi' do bilingüismo na educação de surdos. E. Fernandes (org.).

Sacks, O. (1989). Seeing voices: A journey into the land of the deaf. berkeley.

Saito, D. and Ribas Ulbricht, V. (2012). Learning managent systems and face-to-face teaching in bilingual modality (libras/portuguese). Latin America Transactions, IEEE (Revista IEEE America Latina), 10(5):2168-2174.

Saito, D., Scolari, S., and Felício, M. (2011). O design de material didático e o processo de tradução/interpretação (libras/português): uma aproximação possível. Proceedings of Simpósio Brasileiro de Sistemas Multimídia e Web, WebMedia.

SECOM (2015). Pesquisa Brasileira de Mídia 2015: Hábitos de consumo de mídia pela população brasileira. SECRETARIA DE COMUNICAÇÃO SOCIAL DA PRESIDÊNCIA DA REPÚBLICA, Brasília, 1 edition.

Vygotsky, L., Hanfmann, E., and Vakar, G. (2012). Thought and language. MIT press. 